
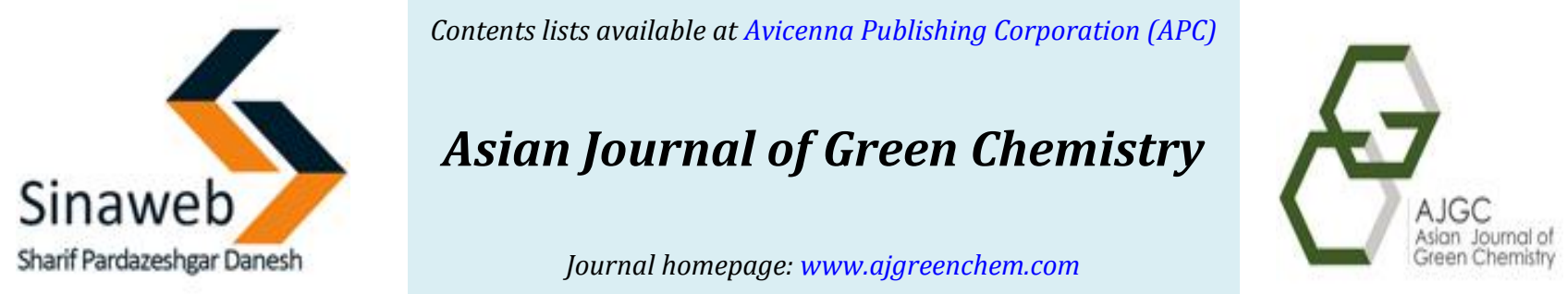

Orginal Research Article

\title{
Green synthesis and characterization of silver nanoparticles using fructose
}

\author{
Elham Arshadi, Sajjad Sedaghat*, Omid Moradi \\ Department of Chemistry, College of Science, Shahr-e-Qods Branch, Islamic Azad University, Shahr-e-Qods, Iran
}

\section{ARTICLE INFORMATION}

Received: 24 August 2017

Received in revised: 16 October 2017

Accepted: 17 October 2017

Available online: 23 Novamber 2017

DOI: 10.22631/ajgc.2017.96293.1020

\section{KEYWORDS}

Green synthesis

Silver nanoparticles

Fructose

Transmission electron microscopy

\begin{abstract}
The green synthesis of nanoparticles is an important branch and a relatively new emerging field in nanotechnology which is easy, environmentally friendly, cost effective, and economically efficient in comparison with the chemical and physical methods. In the present work, for the first time, green synthesis of silver nanoparticles (AgNPs) was carried out by using fructose solution as a reducing agent at room temperature. The silver nanoparticles were characterized by UV-Vis, FTIR, XRD, and TEM analysis. The UV-Vis spectral studies confirmed the surface plasmon resonance of the green synthesized silver nanoparticles. The role of different functional groups in formation of the AgNps was shown by FTIR. X-ray diffraction results confirmed the formation of the the AgNPs and TEM results indicated that the average particle size of the silver nanoparticles was $13.24 \pm 8.591 \mathrm{~nm}$.
\end{abstract}




\section{Graphical Abstract}

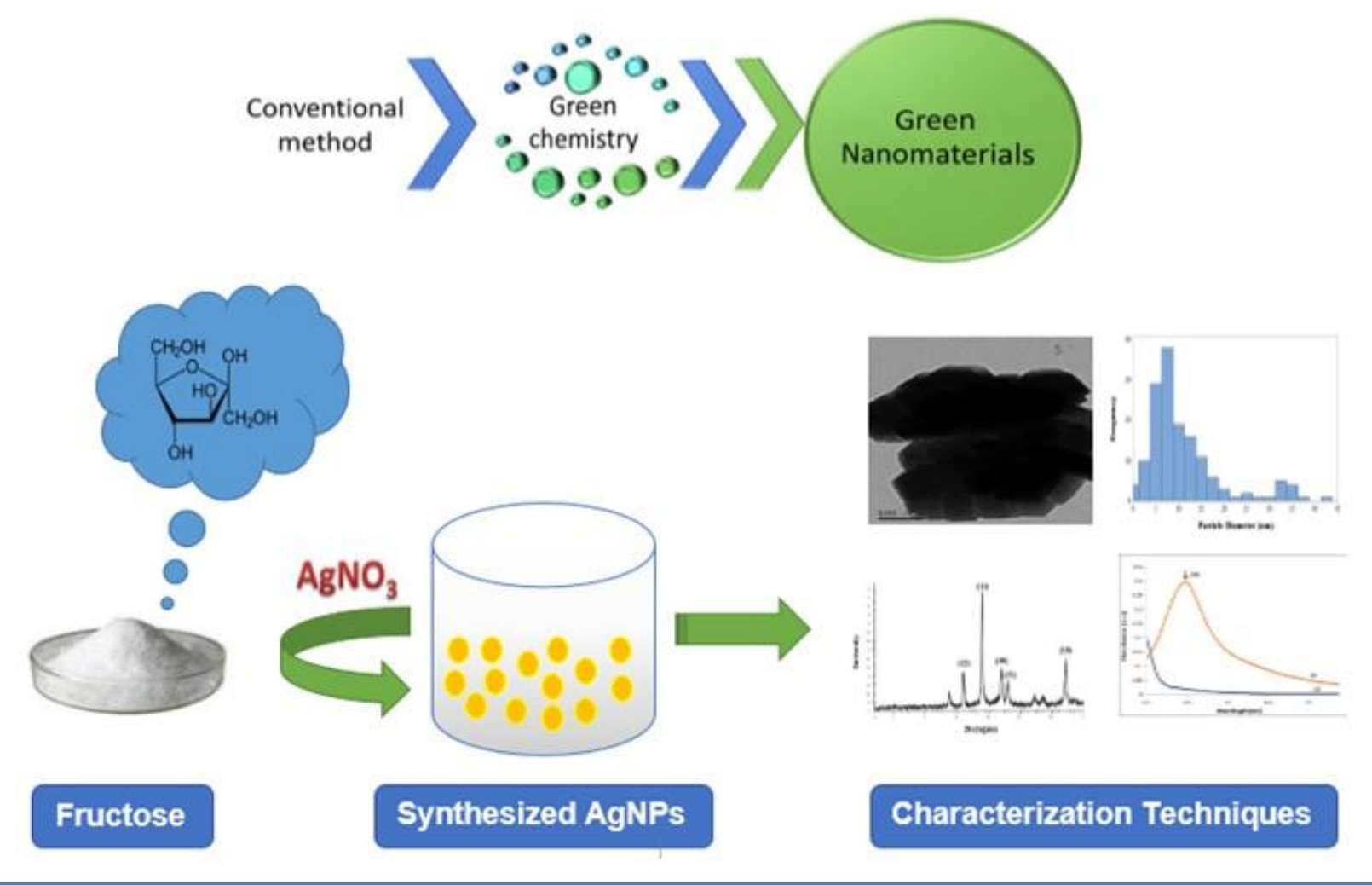

\section{Introduction}

Nanotechnology is a principally attractive area of research related to producing nanoparticles with various sizes, shapes, chemical compositions, dispersity, and possible application for benefit of human beings [1]. One of the most important fields of research in nanotechnology is the synthesis of different nanoparticles such as silver, gold, iron, and etc [2, 3].

Silver nanoparticles (AgNPs) are the most applicable and interesting nanoparticles for researchers. Physicochemical and biological environmental properties, including optical, magnetic, electronic, catalytic activity, and biological properties [4], increasing the applications of nanoparticles in medicine, agriculture, and industries. Generally, nanoparticles are prepared by a variety of chemical and physical methods which are quite expensive and potentially hazardous to the environment, resulting in various biological risks. Biosynthetic routes can actually provide nanoparticles of a better defined size and morphology than some of the physicochemical methods [5]. In green synthesis of nanoparticles, three important rules of green chemistry should be considered: i) choosing an appropriate green solvents, ii) choosing an eco-friendly benign reducing 
agent, and iii) choosing a non-toxic stabilizer [6]. Some natural bioactive compounds which are extracted from enzymes, fungi, bacteria, vitamins, sugars, and plant are appropriate to reduce $\mathrm{Ag}^{+}$ ion from (I) to (0) oxidation state. This is due to the abundances of hydroxyl, aldehyde, ketone, and amino groups that present in these natural resources [7, 8]. Various biological entities that may act as the reducing and capping agents in silver nanoparticles synthesis are summarized in the (Table 1).

In this study, for the first time we successfully synthesized the AgNPs by using fructose as the reducing and capping agent. One of the advantages of this method is being able to use renewable materials like polysaccharides that are eco-friendly agents. These green-synthesized nanoparticles were evaluated by ultraviolet-visible spectroscopy (UV-Vis), transmission electron microscopy (TEM), powder x-ray diffraction (XRD), scanning electron microscopy (SEM), and Fourier transform infrared (FT-IR) spectroscopy.

Table 1. Uses of various biological entities in the synthesis of silver nanoparticles during the period of 2003-2017

\begin{tabular}{|c|c|c|c|}
\hline Biological entity & Characterization, Observation \& Particle size & Shape & Ref. \\
\hline $\begin{array}{l}\text { Satureja intermedia } \\
\text { C.A. Mey aqueous } \\
\text { extract }\end{array}$ & $\begin{array}{l}\text { Synthesized nanoparticles are characterized under } \\
\text { UV-Vis spectroscopy at the range of } 200-800 \mathrm{~nm} \text {. The } \\
\text { peak showed at } 475 \mathrm{~nm} \text {. }\end{array}$ & Spherical & [9] \\
\hline $\begin{array}{l}\text { Pennyroyal water } \\
\text { extract }\end{array}$ & $\begin{array}{l}\text { Nanoparticles were characterized using UV-Vis } \\
\text { absorption spectroscopy, FTIR, XRD, TEM. }\end{array}$ & Spherical & [10] \\
\hline Moringa oleifera & $\begin{array}{l}\text { The color change in reaction medium from pale } \\
\text { yellow to dark brown was observed during the } \\
\text { incubation period. }\end{array}$ & Rectangle & [11] \\
\hline Fenugreek Seeds & $\begin{array}{l}\text { Nanoparticles were characterized using UV-Vis } \\
\text { absorption spectroscopy, FTIR, XRD, SEM. }\end{array}$ & Spherical & [12] \\
\hline $\begin{array}{l}\text { Rumex } \\
\text { hymenosepalus }\end{array}$ & $\begin{array}{l}\text { From TEM analysis, the size of the silver } \\
\text { nanoparticles was measured }(2-40 \mathrm{~nm}) \text {. }\end{array}$ & $\begin{array}{l}\text { Cubic and } \\
\text { hexagonal }\end{array}$ & [13] \\
\hline Phlomis leaf extract & $\begin{array}{l}\text { The particle size of the silver nanoparticles ranged in } \\
\text { size from } 19 \text { to } 30 \mathrm{~nm} \text {, with an average size of } 25 \mathrm{~nm} \text {. }\end{array}$ & Spherical & [14] \\
\hline Satureja hortensis L & $\begin{array}{l}\text { Nanoparticles were characterized using UV-Vis } \\
\text { absorption spectroscopy, FTIR, XRD, TEM. }\end{array}$ & Spherical & [15] \\
\hline $\begin{array}{l}\text { Cydonia oblong seed } \\
\text { extract }\end{array}$ & $\begin{array}{l}\text { Reduction of silver nitrate to silver nanoparticles was } \\
\text { confirmed by UV-visible spectrophotometer, FTIR, } \\
\text { XRD and SEM techniques. }\end{array}$ & Spherical & [16] \\
\hline $\begin{array}{l}\text { Eriobotrya japonica } \\
\text { leaf extract }\end{array}$ & $\begin{array}{l}\text { The prepared AgNPs were spherical in shape, and } \\
\text { their average particle size determined by TEM was } \\
\text { about } 20 \mathrm{~nm} \text {. }\end{array}$ & Spherical & [17] \\
\hline Plukenetia volubilis & Optical shaped nanoparticles in the size of $4-25 \mathrm{~nm}$. & Optical & [18] \\
\hline $\begin{array}{l}\text { Ziziphora tenuior L } \\
\text { Water Extract }\end{array}$ & $\begin{array}{l}\text { Nanoparticles were characterized using UV-Vis } \\
\text { absorption spectroscopy FTIR, XRD, TEM. }\end{array}$ & $\begin{array}{l}\text { Cubic or } \\
\text { Spherical }\end{array}$ & [19] \\
\hline
\end{tabular}




\begin{tabular}{|c|c|c|c|}
\hline $\begin{array}{l}\text { Seed exudates of } \\
\text { Sinapis arvensis }\end{array}$ & $\begin{array}{l}\text { Spherical shaped nanoparticles in the size of } 55-90 \\
\mathrm{~nm} \text {. }\end{array}$ & Spherical & {$[20]$} \\
\hline $\begin{array}{l}\text { Sargassum Muticum } \\
\text { aqueous extract }\end{array}$ & $\begin{array}{l}\text { The biosynthesized silver nanoparticles have } \\
\text { spherical shapes and the particle size ranges from } 5 \\
\text { to } 15 \mathrm{~nm} \text { with a mean size of } 8 \mathrm{~nm} \text {. }\end{array}$ & Spherical & {$[21]$} \\
\hline Annona Reticulata L & $\begin{array}{l}\text { Reaction mixtures turned dark brown, predominance } \\
\text { of silver nano sized crystallites (12.72 nm) after } \\
\text { short incubation period. }\end{array}$ & Cubic & {$[22]$} \\
\hline $\begin{array}{l}\text { Citrullus lanatus } \\
\text { Fruit Rind Extract }\end{array}$ & $\begin{array}{l}\text { This method yields stable, spherical silver } \\
\text { nanoparticles with an average hydrodynamic } \\
\text { diameter of } 17.96 \pm 0.16 \mathrm{~nm} \text {. }\end{array}$ & Spherical & {$[23]$} \\
\hline $\begin{array}{l}\text { Leaf extract of } \\
\text { Thevetia peruviana } \\
\text { Juss }\end{array}$ & $\begin{array}{l}\text { The obtained nanoparticles were highly uniform with } \\
\text { average size of } 18.1 \mathrm{~nm} \text {. }\end{array}$ & $\begin{array}{l}\text { Crystalline } \\
\text { and } \\
\text { spherical }\end{array}$ & {$[24]$} \\
\hline $\begin{array}{l}\text { Salmonella } \\
\text { typhirium }\end{array}$ & $\begin{array}{l}\text { From TEM analysis, the size of the silver } \\
\text { nanoparticles was measured }(87 \mathrm{~nm}) .\end{array}$ & Spherical & {$[25]$} \\
\hline $\begin{array}{l}\text { Pedalium murex leaf } \\
\text { extract }\end{array}$ & $\begin{array}{l}\text { The formation of nanoparticles was observed within } \\
20 \text { min. }\end{array}$ & $\begin{array}{l}\text { Cubic or } \\
\text { Spherical }\end{array}$ & {$[26]$} \\
\hline Ziziphus Jujuba & $\begin{array}{l}\text { Nanoparticles were characterized using UV-Vis } \\
\text { absorption spectroscopy, FTIR, XRD, TEM. }\end{array}$ & Crystalline & {$[27]$} \\
\hline $\begin{array}{l}\text { Schizophyllum } \\
\text { radiatum }\end{array}$ & $\begin{array}{l}\text { Scanning electron microscopy micrograph showed } \\
\text { formation of well-dispersed silver nanoparticles in } \\
\text { the range of } 10-40 \mathrm{~nm} \text {. }\end{array}$ & Spherical & {$[28]$} \\
\hline
\end{tabular}

\section{Experimental}

\section{Matreials and methods}

Fructose $\left(\mathrm{C}_{6} \mathrm{H}_{12} \mathrm{O}_{6}\right)$ and silver nitrate $\left(\mathrm{AgNO}_{3}, 99.80 \%\right)$ were purchased from Merck (Germany). All the samples were used without any further treatment. All aqueous solutions were prepared using double-distilled water. The UV-Visible spectra were recorded over the 325-800 nm range with a UV Bio-TEK UV-Visible spectrophotometer. Deionized water was used for diluting the samples and then filled in a quartz cuvette with $1 \mathrm{~cm}$ path length. The crystalline structure of the silver nanoparticles was investigated by X-ray analysis (XRD, Inel, EQUINX 3000). Transmission electron microscopy was (TEM, Carl Zeiss, EM $10 \mathrm{C}-100 \mathrm{kV}$ ) employed to evaluate the morphology and particle size of the AgNPs. Scanning electron microscopy (SEM, HITACHI S-4160) was used to investigate the shape, size and the surface area of the silver nanoparticles. FT-IR spectral analysis was conducted within a 4000-400 $\mathrm{cm}^{-1}$ range, with a Shimadzu spectrophotometer (Model $8400 \mathrm{~S}$ ), using $\mathrm{KBr}$ pellets mixed with the dried and purified nanoparticles. The instrument was operated under the diffuse reflectance mode with a resolution of $4 \mathrm{~cm}^{-1}$ and the average scans of 50 . 
For the synthesis of AgNPs, a certain volume of the fructose solution ( $5 \mathrm{~mL}$ ) was added to the $\mathrm{AgNO}_{3}$ solution $(0.01 \mathrm{M})$ and the volume was adjusted to $45 \mathrm{ml}$ with de-ionized water. Then two solutions were mixed drop by drop while and the mixture was stirring. Initial $\mathrm{pH}$ of solution was about 7.5 which changed to 5.6 at the end of reaction. In this method, $\mathrm{AgNO}_{3}$ was reduction by fructose solution as a reducing agent at room temperature.

\section{Results and discussion}

\section{UV-Vis Spectroscopy}

Producing and stabilizing of the reduced silver nanoparticles in the colloidal solution was monitored by using UV-Vis spectrophotometer analysis. UV-Vis spectroscopy is one of the most important techniques to identify the formation and stability of the silver nanoparticles in the aqueous solution [29]. Silver nanoparticles are known to exhibit at maximum in the range of 400 to $500 \mathrm{~nm}$. The UV-Vis absorption spectra recorded for AgNPs solution and suspension in water are shown in Figure 1. The maximum absorption at $436 \mathrm{~nm}$ can be attributed to the plasma resonance absorption of the silver nanoparticles.

\section{XRD analysis}

The x-ray diffraction analyses were carried out to determine the various phases of the silver nanoparticles. Figure 2 demonstrates the XRD pattern of the dried synthesized Ag nanoparticles by fructose. The spectrum exhibited five distinct separate peaks at $2 \theta$ of about $32.04^{\circ}, 38.10^{\circ}, 44.37^{\circ}$, $46.17^{\circ}, 63.57^{\circ}$, and $81.67^{\circ}$ are associated with (122), (111), (200), (231), (220), and (311) orientations, respectively, which are matched to the face-centered cubic (fcc) phase of $\mathrm{Ag}^{\circ}$. The (111) peak oriented the most amount of the absorption of Ag nanoparticle and the absence of other peaks shows that the AgNPs are pure [30]. The average crystalline size of the silver nanoparticles was estimated using Equation 1 (Debye-scherrer equation)

$$
\mathrm{D}=\frac{K \lambda}{\beta \cos \theta}
$$

Where $D$ is the average crystalline diameter size (A), $K$ is a constant (0.9), $\lambda$ is the $x$-ray wavelength used $(\lambda=1054 \AA)$, $\mathrm{b}$ is the width of the XRD peak and $\Theta$ is the Bragg angle (degrees). The average grain crystalline size of AgNPs was estimated to be approximately $14 \mathrm{~nm}$. 


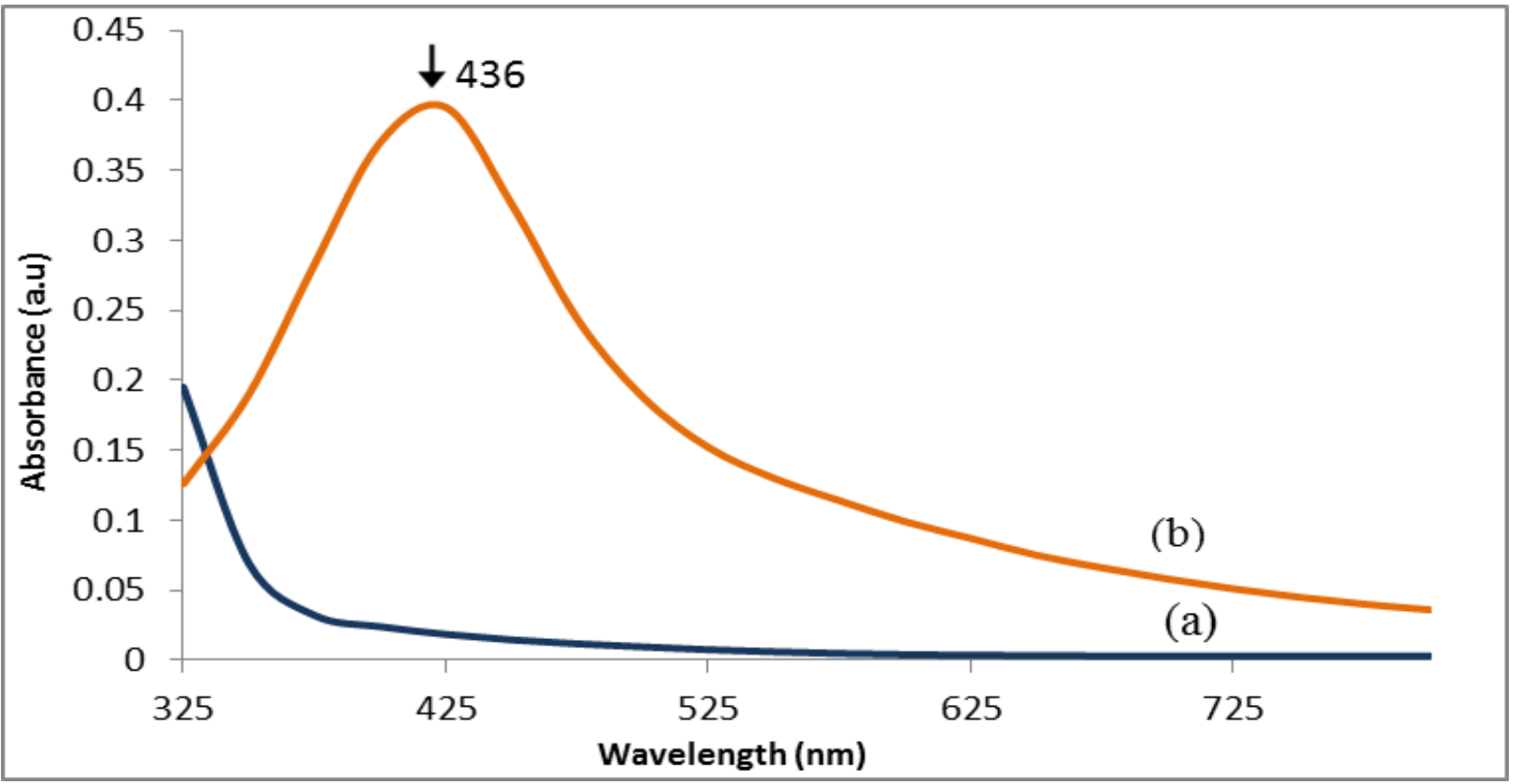

Figure 1. UV-Vis absorption spectra of a) fructose solution and, b) AgNPs dispersed in water

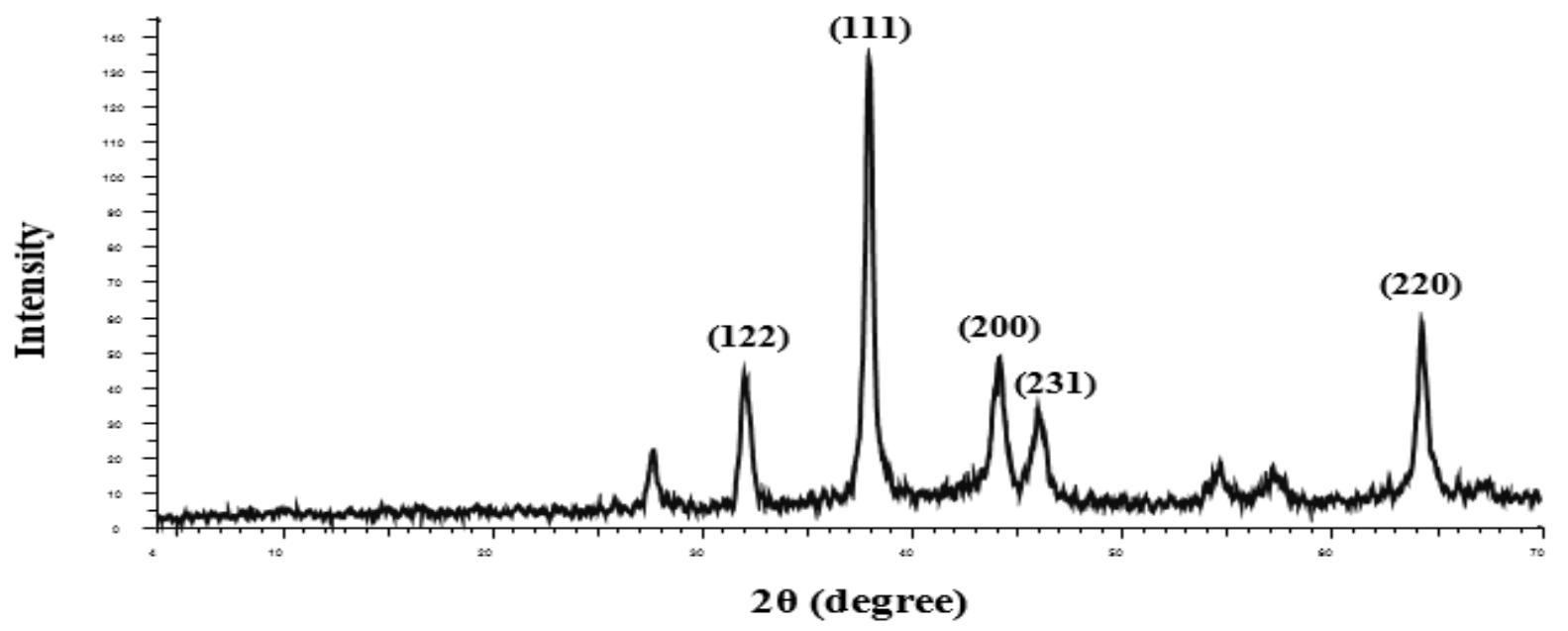

Figure 2. XRD patterns of AgNPs synthesized by fructose solution

\section{FTIR analysis}

Fourier transform infrared spectroscopy (FT-IR) measurements were carried out to identify the possible biomolecules responsible for functional groups involved in reduction, capping, and efficient stabilization of newly synthesized silver nanoparticles [31]. The FT-IR spectra of the fructose solution and green synthesized silver nanoparticles that measured in absorption mode are 
demonstrated in Figure 3. The fructose solution spectrum consists of several bands at 3391, 1035.4, $2930.3,776.79,1642$, and $1425.7 \mathrm{~cm}^{-1}$. Table 2 illustrates possible vibration of functional groups in fructose powder. The strong peak at $3391 \mathrm{~cm}^{-1}$ corresponded to $(-\mathrm{OH})$ stretching, which is due to phenolic compounds present in the fructose solution. The band at $2930.3 \mathrm{~cm}^{-1}$ was attributed to alkane $\mathrm{C}-\mathrm{H}$ stretching vibration. The peak at $1035.4 \mathrm{~cm}^{-1}$ was corresponded to (C-0) stretching. The peak at $1642 \mathrm{~cm}^{-1}$ corresponded to $(\mathrm{C}=\mathrm{C})$ stretching vibration of aromatic rings. Previous studies confirmed that the hydroxyl groups have a stronger ability to interact with nanoparticles and therefore the secondary metabolites containing hydroxyl group may act as capping agents for formation of the stable silver nanoparticles.

Table 2. The list of possible vibration of functional groups in fructose powder

$\begin{array}{ccc}\text { Functional group } & \text { Type of vibration } & \text { Frequency }\left(\mathrm{cm}^{-1}\right) \\ \text { O-H } & \text { Phenols stretch } & 3391 \\ \text { C=C } & \text { Aromatic stretch } & 1642 \text { and } 1425.7 \\ \text { C-H } & \text { Alkyl stretch } & 2930.4 \\ \text { C-O } & \text { Stretch } & 1035.4 \\ & \text { Long chain band } & 776.79\end{array}$

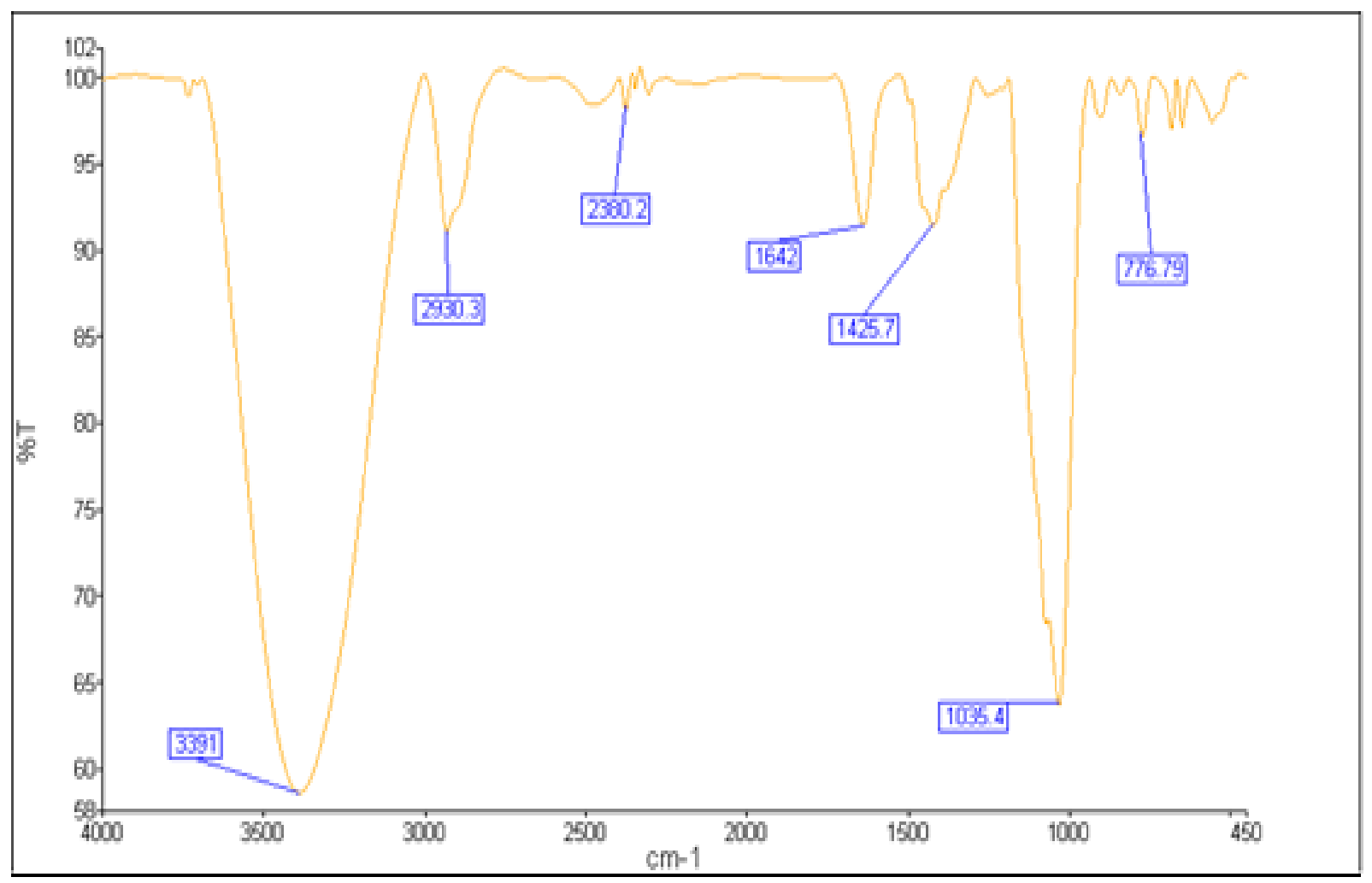

Figure 3. The FT-IR spectra of the green synthesized AgNPs from fructose solution 


\section{TEM analysis}

The silver nanoparticles synthesized by fructose were studied using transmission electron microscopy (TEM). The TEM image confirmed the formation of the silver nanoparticle at nano-size. As can be seen in Figure 4, most of the AgNPs are well dispersed and have an angular shape with an average particle size of $13.24 \pm 8.591$. The method used in the present work allowed obtaining AgNPs with smaller sizes in comparison with different studies using other biological compounds as reducer and stabilizer agents reported in literature. Having a control over the size and structure of the resultant nanoparticles can be related to the interactions between the bio-compounds (including polysaccharides, proteins, polyphenols, and phenolic) and metal atoms.
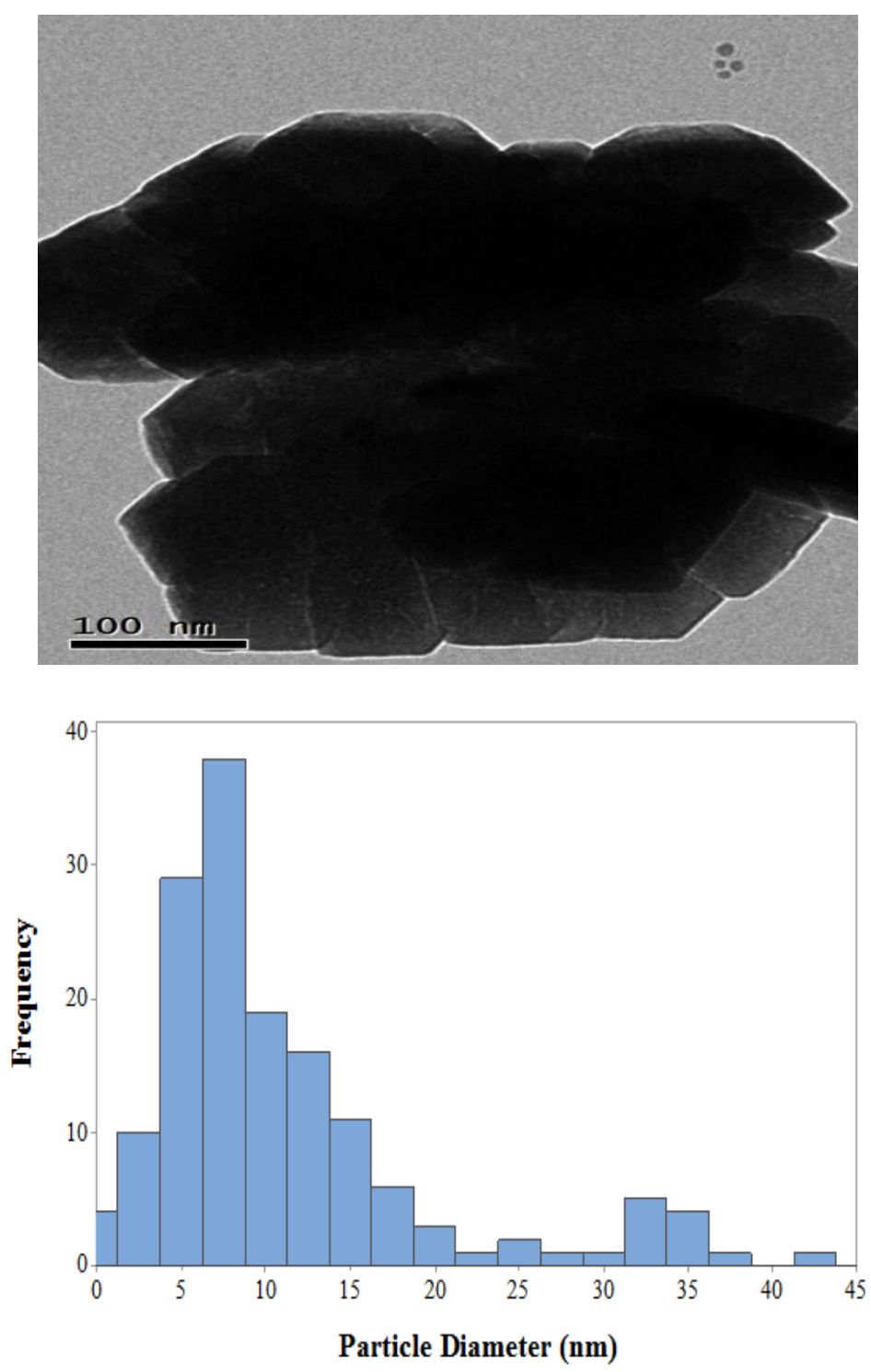

Figure 4. TEM images and corresponding size of AgNPs synthesized by fructose solution 


\section{Conclusion}

Silver nanoparticles with an average particle size of $13.24 \pm 8.591 \mathrm{~nm}$ and angular shape were synthesized using the fructose at room temperature. Silver nanoparticles were characterized by UV-Vis, FT-IR, TEM, and XRD. The UV-Vis spectral studies confirmed the surface plasmon resonance of the green synthesized silver nanoparticles. The green synthesis method is a simple, eco-friendly, low cost, and capable of producing AgNPs at room temperature. This rapid synthesis technique can be a promising method for the preparation of other metal nanoparticles and can be valuable in environmental, bio-technological, pharmaceutical, and medical applications.

\section{Acknowledgments}

The authors are thankful to the Islamic Azad University, Shahr-e-Qods branch for their support.

\section{Disclosure statement}

No potential conflict of interest was reported by the authors.

\section{References}

[1]. Karimi J., Mohsenzadeh S. J. Med. Sci., 2013, 111:64

[2]. Muthoosamy K., Bai R.G., Abubakar I.B., Sudheer S.M., Lim H.N., Loh H.S., Huang N.M., Chia Ch., Manickam S. Int. J Nanomedicine, 2015, 10:1505

[3]. Allafchian A.R., Majidian Z., Ielbeigi V., Tabrizchi M. Anal. Bioanal. Chem., 2016, 408:839

[4]. Phanjom P., Ahmed G. Nanosci Nanotechnol., 2015, 5:14

[5]. Awwad A.M., Salem N.M. Nanosci Nanotechnol., 2012, 2:125

[6]. Darroudi M., Bin Ahmad M., Ibrahim A. Int. J. Nanomed., 2011, 6:569

[7]. Azmi A.A., Ahyat N.M. Malaysian Journal of Analytical Sciences, 2015, 6:1187

[8]. Jitendra M., Amla B., Abhijeet S., Madan M.S. Adv. Nat. Sci: Nanosci. Nanotechnol., 2014, 5:043002

[9]. Firoozi S., Jamzad M., Yari M. J Nanostruct Chem., 2016, 6:357

[10]. Sedaghat S., Esmaeili Agbolag A., Bagheriyan S. J Nanostruct Chem., 2016, 6:25

[11]. Nayak. D., Pradhan. S., Ashe. S., Rauta. PR. J Colloid Interface Sci., 2015, 457:329

[12]. Meena R.K., Chouhan N. Res. J. Recent Sci., 2015, 4:47

[13]. Leon E.R., Palomares R.I., Navarro R.E., Urbina R.H., Tanori J., Palomares C.I., Maldonado A. Nanoscale Res. Lett., 2013, 8:318

[14]. Allafchian A.R., Mirahmadi-Zare S.Z., Jalali S.A.H., Hashemi S.S. J Nanostruct Chem, 2016, 6:129 [15]. Afshar P., Sedaghat S. Curr. Nanosci., 2016, 1:90 
[16]. Zia F., Ghafoor N., Iqbal M., Mehboob S. Appl Nanosci., 2016, 6:1023

[17]. Rao B., Tang R. Adv. Nat. Sci.: Nanosci. Nanotechnol., 2017, 8:015014

[18]. Kumar B., Smita K., Cumbal L., Debut A. Saudi J Bio Sci., 2014, 21:605

[19]. Sedaghat S., Afshar P. Journal of Applied Chemical Research, 2016, 1:103

[20]. Khatami M., Pourseyedi S., Khatami M., Hamidi H., Zaeifi M., Soltani L. Bioresources and

Bioprocessing, 2015, 2:19

[21]. Azizi S., Namvar F., Mahdavi M., Bin Ahmad M., Mohamad R. Materials, 2013, 6:5942

[22]. Ghotekar S.K., Pande S.N., Pansambal S.S., Sanap D.S., Mahale K.M., Sonawane B. World Journal of Pharmacy and Pharmaceutical Sciences, 2015, 4:1304

[23]. Ndikau M., Noah N.M., Andala D.M., Masika E. International Journal of Analytical Chemistry, 2017, 1:1

[24]. Oluwaniyi O.O., Haleemat I., Alabi B., Bodede O., Labulo Ayomide H., Oseghale Charles O. Appl Nanosci., 2016, 6:903

[25]. Ghorbani H.R. Journal of Nanostructure in Chemistry, 2013, 3:29

[26]. Anandalakshmi K., Venugobal J., Ramasamy V. Appl Nanosci., 2016, 6:399

[27]. Gavade NL., Kadam AN., Suwarnkar MB., Ghodake VP., Garadkar KM. Spectrochim Acta A Mol

Biomol Spectrosc., 2015, 136:953

[28]. Metuku R.P., Pabba S., Burra S., Gudikandula K., Singara Charya M.A. 3 Biotech, 2014, 4:227

[29]. Ramar M., Manikandan B., Raman T., Arunagirinathan K., Palanisam S. Molecular and Biomolecular Spectroscopy, 2015, 138:120

[30]. Abidin Ali Z., Yahya R., Devi Sekaran S., R. Puteh. Advances in Materials Science and Engineering, 2016, 1:7

[31]. Shameli K., Bin Ahmad M., Jazayeri D., Sedaghat S., Shabanzadeh P., Jahangirian H., Mahdavi M., Abdollahi Y. Int. J. Mol. Sci., 2012, 13:6639

How to cite this manuscript: Elham Arshadi, Sajjad Sedaghat*, Omid Moradi. Green synthesis and characterization of silver nanoparticles using fructose. Asian Journal of Green Chemistry, 2018, 2, 41-50. DOI: 10.22631/ajgc.2017.96293.1020 